\title{
Role of Ureaplasma Species in Neonatal Chronic Lung Disease: Epidemiologic and Experimental Evidence
}

\author{
ROSE MARIE VISCARDI AND JEFFREY D. HASDAY
}

Department of Pediatrics [R.M.V.], Department of Medicine [J.D.H.], University of Maryland School of Medicine, Baltimore, Maryland 21201

\begin{abstract}
The contribution of Ureaplasma respiratory tract colonization to the pathogenesis of bronchopulmonary dysplasia in preterm infants has been debated for over $20 \mathrm{y}$. We review the current understanding of the role of inflammation in altered developmental signaling in the preterm lung and the evidence from human studies and experimental models that Ureaplasma-mediated inflammation produces the BPD phenotype. We propose that Ureaplasma infection initiated in utero and augmented postnatally by exposure to volutrauma and oxygen elicits a sustained, dysregulated inflammatory response in the immature lung that impairs alveolarization, and stimulates myofibroblast proliferation and excessive collagen and elastin deposition. Potential strategies to prevent or ameliorate the effects of Ureaplasma infection in utero and in the preterm lung are discussed. (Pediatr Res 65: 84R-90R, 2009)
\end{abstract}

$\mathrm{W}$ ith recent improvements in perinatal care, bronchopulmonary dysplasia (BPD) has become a disease limited to the most immature infants (1), occurring in $30 \%$ of infants $\leq 28$ wks gestation (2). Compared with the lung histology observed in the ventilated preterm lung during the preexogenous surfactant era, the 'new' BPD is characterized by more uniform inflation, fewer but larger alveoli, and less fulminant, but persistent inflammation (3). Studies of human infants and experimental animal models indicate that the central event in BPD pathogenesis is the interruption of normal developmental signaling during early stages of lung development by lung injury that is often initiated in utero by intrauterine infection and a subsequent dysregulated inflammatory response (1).

In 1988, three independent groups published single center cohort studies linking respiratory tract colonization with the Mycoplasma species Ureaplasma urealyticum with the development of BPD in preterm infants (4-6). The studies differed in eligibility criteria, culture sites (eye, throat, vagina, rectum (4), stomach (5), nasopharynx $(5,6)$, trachea $(5,6)$, and blood (6)), and sampling frequency, but each study contributed important observations concerning Ureaplasma colonization in the preterm population. They observed that colonization 1) was inversely related to gestational age (4-6), 2) occurred in some infants delivered with intact membranes, suggesting in utero acquisition (6), and persisted in some infants until discharge (4). Twenty years later, more than 30 additional studies with inconsistent results, 2 meta-analyses $(7,8)$, and 3

Received November 3, 2008; accepted January 12, 2009.

Corresponding Author: Rose Marie Viscardi, M.D., 29, S Greene Street, Rm GS 110, Baltimore, M.D. 21201, Phone: 410-716-1913, Fax: 410-716-0404; e-mail: rviscard@ umaryland.edu

Financial support: Supported by HL71113, HL087166, and HD056424 comprehensive reviews (9-11) have been published without resolving the controversy of the importance of Ureaplasma respiratory tract colonization to the development of $\mathrm{BPD}$, and no effective prevention or treatment strategies have been developed. This review will summarize the epidemiologic and experimental evidence that support a causative role of Ureaplasma spp. in BPD and explore potential therapeutic options.

\section{Ureaplasma Species}

A member of the Mollicutes class, Ureaplasma, is comprised of two species and 14 serovars. U. parvum contains serovars $1,3,6$, and 14 , and $U$. urealyticum contains the remaining serovars (10). All serovars lack cell walls, exhibit limited biosynthetic abilities, hydrolyze urea to generate ATP, and adher to human mucosal surfaces (10). The sequenced $U$. parvum serovar 3 genome is the second smallest known genome with 751,717 base pairs (12). Genes comprise $93 \%$ of the genome with 613 predicted protein-coding genes and 39 RNA-coding genes. About half of the protein-coding genes have been assigned biologic functions, $19 \%$ of the genes are similar to hypothetical genes of unknown function in other species, and $28 \%$ of the genes are unique hypothetical genes with no significant similarities to putative or known genes in other organisms.

\section{Ureaplasma spp. Virulence Factors}

Some serovars have greater association with adverse pregnancy outcomes than others (13-15). Although $U$. parvum is more commonly isolated from clinical adult vaginal and infant respiratory specimens $(13,15)$, and is the predominant species in newborn serum and/or cerebrospinal fluid (CSF) samples detected by PCR (16), Abele-Horn et al. (13) reported a higher rate of BPD in $U$. urealyticum respiratory tract colonized infants. In contrast, Katz et al. (17) observed no difference in prevalence of either species detected by PCR between infants with and without BPD. To date, there has been no study that has determined the relationship of specific serovars and the development of BPD.

Previously proposed ureaplasmal virulence factors include IgA protease, urease, phospholipases $\mathrm{A}$ and $\mathrm{C}$, and production

Abbreviations: AF, Amniotic fluid; BPD, bronchopulmonary dysplasia; CSF, cerebrospinal fluid; IAI, intraamniotic infection; LPS, lipopolysaccharide; NF-кB, nuclear factor-kappa B; PMA, post-menstrual age; TLR, Tolllike receptor 
of hydrogen peroxide (12). These factors may allow the organism to evade mucosal immune defenses by degrading $\operatorname{IgA}$, and injuring mucosal cells through the local generation of ammonia, membrane phospholipid degradation and prostaglandin synthesis, and membrane peroxidation, respectively. The ureaplasmal MB antigen that contains both serovarspecific and cross-reactive epitopes, is the predominant antigen recognized during ureaplasmal infections in humans. It exhibits highly variable size in vitro and in clinical isolates in vivo, suggesting that antigen size variation may be another mechanism through which the organism evades host defenses (10). Although functionally active IgA protease and phospholipase A and C were found in Ureaplasma spp., the genes that code for these proteins have not been identified in the $U$. parvum serovar 3 genome (12). The ureaplasmal enzymes may have unique sequences compared with analogous genes in other species.

\section{Association of Ureaplasma Respiratory Tract Colonization with Chronic Lung Disease in Preterm Infants}

Because Ureaplasma is a commensal in the adult female genital tract, it has been considered of low virulence. However, its presence has been consistently associated with multiple obstetrical complications including infertility, histologic chorioamnionitis, stillbirth, preterm delivery, neonatal morbidity, and perinatal death $(10,11,18)$. Ureaplasma spp. are the most common organisms isolated from amniotic fluid (AF) and infected placentas $(18,19)$. The vertical transmission rate is inversely related to gestational age $(20,21)$ and increases with duration of rupture of membranes (14). Detection of respiratory tract colonization with Ureaplasma by PCR suggests that colonization in very low birth weight infants (VLBW $<1500 \mathrm{~g})$ is higher $(25-48 \%)(10,22)$ than previously reported for culture-based studies (20\%) (7).

The contribution of Ureaplasma respiratory tract colonization to the development of BPD has been debated. A meta-analysis of 17 clinical studies published before 1995 supported a significant association between Ureaplasma respiratory tract colonization and development of BPD defined as oxygen dependence at 28 to $30 \mathrm{~d}$ postnatal age (7), but there were insufficient data concerning the relationship of Ureaplasma colonization and BPD at 36 wk postmenstrual age (PMA). Most individual studies published since 1995 have supported the association of Ureaplasma and BPD (23-28), but other studies failed to show a significant association (29-32). Differences in population characteristics, clinical practices such as antenatal and postnatal steroid use, and culture methodology may account for differences in study conclusions.

Since interpretation of many of the studies published to date has been hampered by inclusion of small numbers of subjects resulting in inadequate power and possible sampling bias, Schelonka et al. (8) conducted a meta-analysis of 36 studies published between 1988 and 2004 involving 3000 preterm infants. Studies were excluded if the proportion of eligible subjects was not described. Included studies were grouped by definition of BPD as oxygen requirement at 28 postnatal days (BPD28; $n=23$ studies, 2216 subjects) or 36 wk PMA (BPD36; $n=8$ studies, 751 subjects). There was a 1.6 (BPD36) to 2.8 (BPD28) -fold increased risk for BPD in Ureaplasma colonized infants in the pooled studies. However, substantial heterogeneity was detected, decreasing the precision of the risk estimates. Factors that were related to higher reported odds of an Ureaplasma-BPD association included earlier year of publication, small sample size, surfactant use $>90 \%$, and endotracheal culture as the only method of diagnosis. Studies published since the last meta-analysis support the Ureaplasma respiratory colonization-BPD association (22,33), particularly for the subset of Ureaplasma-colonized infants exposed to chorioamnionitis and leukocytosis at birth (33).

The timing and duration of exposure of the developing lung to Ureaplasma may be variable and the relationship to pulmonary outcomes is not fully understood. The rate of vertical transmission increases with an increase in duration of rupture of membranes (14), suggesting that for many infants, neonatal infections are the result of ascending infection that occurs at or near parturition. However, Ureaplasma species have been detected in AF as early as the time of genetic amniocentesis (16-20 wk) in $0.36-2.8 \%$ (culture-based methods) (34-36) to $12.8 \%$ (PCR-based methods) (37) asymptomatic women. While the majority of women in whom early amniotic cavity infection is detected deliver at term (37), those with elevated AF IL-6 levels and midtrimester subclinical Ureaplasma intrauterine infection have increased risk for adverse pregnancy outcome including fetal loss and preterm delivery (38). Duration of exposure of the preterm lung postnatally may also be important. Although most epidemiologic studies focused on identifying colonization within the first few days of life, CastroAlcaraz et al. (39) observed that persistent, but not transient, Ureaplasma respiratory tract colonization is a risk factor for BPD. Mortality due to respiratory complications is significantly higher in colonized infants $(6,21)$. The risk of a combined outcome measure of BPD or death due to lung disease was 4.2-fold higher in Ureaplasma colonized than in noncolonized VLBW infants (22).

\section{Systemic Ureaplasma Infections in Preterm Infants}

Although the relationship of Ureaplasma respiratory tract colonization with BPD has been extensively studied, less is known about the incidence of invasive disease defined as detection in blood and/or CSF, and its relationship with neonatal outcomes. In 2 large prospective cohorts, Ureaplasma was detected in $17 \%$ of cord blood cultures (40) and $23.6 \%$ serum and/or CSF PCR samples (16), but invasive disease was not associated with BPD at $36 \mathrm{wk}$ PMA in either cohort. Overall, almost half of subjects were Ureaplasma positive in one or more compartments (respiratory, blood, CSF), confirming that this organism is the most common pathogen affecting this population (16). 


\section{Experimental Evidence for Causative Role of Ureaplasma spp. in BPD}

Elucidating the mechanisms by which Ureaplasma may contribute to BPD pathogenesis will not only provide evidence for a causal relationship, but also identify potential targets for interventions to prevent or ameliorate BPD in colonized infants. In this section, we will review our current understanding of the role of inflammation in altered developmental signaling in the preterm lung and the evidence from human studies, and in vitro and in vivo models that Ureaplasma-mediated inflammation produces the BPD phenotype. As shown in Fig. 1, we propose that Ureaplasma infection initiated in utero and augmented postnatally by exposure to volutrauma and oxygen elicits a sustained, dysregulated inflammatory response in the immature lung that impairs alveolarization, and stimulates myofibroblast proliferation, and excessive collagen and elastin deposition.

\section{Chronic Inflammation in the Immature Lung Alters Developmental Signaling and Fibrosis}

Infection-induced stimulation of inflammatory cytokines may be the causative link between intrauterine infection and neonatal lung injury. AF concentrations of IL-1ß, IL-6, TNF- $\alpha$, and IL- 8 were higher in pregnancies producing infants who developed BPD than in pregnancies producing infants without BPD (41). In a series of longitudinal studies comparing temporal changes in inflammatory mediators and their inhibitors in tracheal aspirates from preterm infants, with and without lung disease, we and others have shown an imbalance of pro- and anti-inflammatory cytokines in infants who develop BPD (42-46). The increase in expression of pulmonary pro-inflammatory cytokines, in concert with a decreased capacity to down-regulate this response in infants who develop BPD, suggest that persistent endogenous generation of these cytokines might contribute to chronic lung injury and inflammation.

In transgenic mice, overexpression of TNF- $\alpha$, IL-6, or IL-11 inhibited alveolarization, indicating that prolonged exposure of the preterm lung to a pro-inflammatory environment contributes to abnormal alveolar septation (1). This contention is further supported by Bry and coworkers (47) who developed a bitransgenic CCSP-rtTA-(tetO)-CMVIL-1ß mouse in which IL-1ß was expressed under conditional control in airway epithelial cells in the fetal and neonatal lung. IL-1ß expression increased from E14.5 until late gestation and decreased postnatally. Postnatal growth was impaired and mortality was higher in the IL- $1 \beta$ expressing newborn mice. The newborn lungs demonstrated many features of the BPD phenotype, including disrupted alveolar septation and capillary development, and disordered $\alpha$-smooth muscle actin (myofibroblast marker) and elastin deposition in alveolar septa of distal airspaces (47). These abnormalities were attributed to expression of CXC and CC chemokines resulting in recruitment of neutrophils and macrophages to the developing lung. This model demonstrates that inflammation initiated in utero early in lung development is sufficient to produce the BPD phenotype.

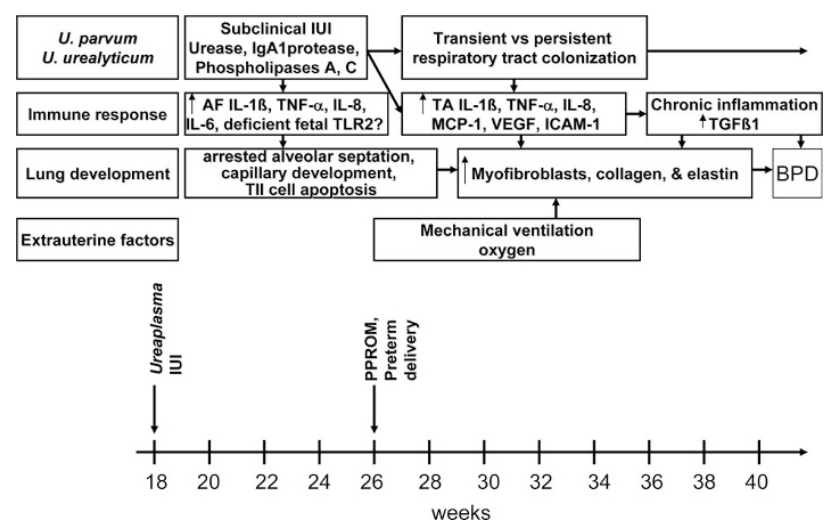

Figure 1. Proposed model for role of Ureaplasma infection in BPD pathogenesis. In this schematic, prolonged intraamniotic exposure of the fetal lung to Ureaplasma infection and maternal and fetal derived cytokines, recruits inflammatory cells, and alters TGFß1 developmental signaling in the lung. Postnatal exposure to ventilation and oxygen augments this pro-inflammatory response leading to arrested alveolarization, disordered myofibroblast proliferation, and excessive collagen and elastin deposition.

The effects of prolonged exposure to pro-inflammatory cytokines on alveolarization may be mediated by upregulation of TGF $\beta_{1}$. TGF $\beta_{1}$ plays a role in lung morphogenesis, repair of lung injury, airway remodeling, lung fibrosis, and BPD (48). TGF $\beta$ was detected at sites of lung injury in association with myofibroblast proliferation in lungs of infants dying with RDS, implicating TGF $\beta$ in the preterm lung response to injury (49). TGF $\beta_{1}$ overexpression in the lungs of newborn transgenic mice (50) or inoculation with $\mathrm{TGF} \beta_{1^{-}}$ expressing adenoviral vectors in the newborn rat lung (51) produces a phenotype similar to human BPD with arrested lung saccular and vascular development. TNF- $\alpha$ (52) or IL-1 $\beta$ (53) overexpression in rat lung produces lung fibrosis due to TGF $\beta_{1}$ stimulation, and induction of myofibroblasts. TNF- $\alpha$, $\mathrm{IL}-1 \beta$, and $\mathrm{TGF} \beta_{1}$ are each elevated in tracheal aspirates of infants who progress to BPD $(42,43,54)$. Taken collectively, these data suggest that prolonged exposure of the developing lung to inflammation contributes to BPD by disrupting normal TGFß developmental signaling.

\section{Ureaplasma spp. Modulate the Inflammatory Response}

Recent human and experimental studies confirm that exposure of the fetal and/or newborn lung to Ureaplasma contributes to altered lung development, sustained inflammation, and fibrosis. In a review of lung pathology of archived autopsy specimens from Ureaplasma-infected preterm infants, we observed moderate to severe fibrosis and increased elastic fiber accumulation $(55,56)$. In addition, we observed increased numbers of myofibroblasts (Fig. 2) and TNF- $\alpha$ and TGF $\beta_{1^{-}}$ immunoreactive cells (Fig. 3) in all Ureaplasma-infected infants compared with noninfected gestational controls and infants who died with pneumonia from other causes $(55,56)$. The increase in fibrosis and elastic fiber accumulation in the distal lung correlated spatially and temporally with the presence of TGF $\beta_{1}$-positive macrophages, suggesting that these are closely linked.

Animal Ureaplasma pneumonia models developed in nonhuman primates and mice demonstrate that an infection estab- 


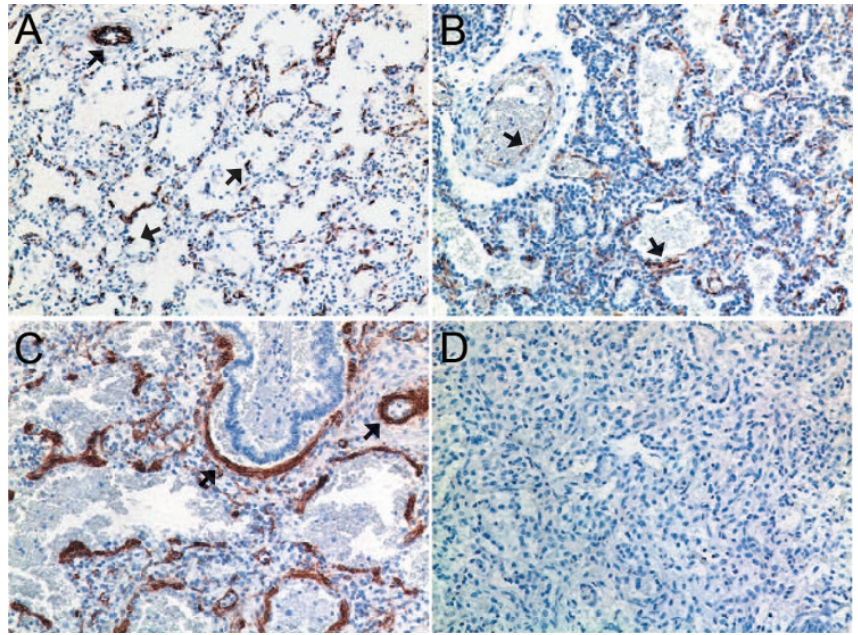

Figure 2. Comparison of $\alpha$-smooth muscle actin ( $\alpha$-SMA) immunostaining in human preterm lung specimens. (A) Control nonventilated infant at $23 \mathrm{wk}$ GA; (B) Other pneumonia case at 24 wk GA ventilated for $2 \mathrm{~d}$; and (C) Ureaplasma-infected infant at 26 wk GA ventilated for $20 \mathrm{~d}$. Lung sections were incubated with anti- $\alpha$-SMA antibody and counterstained with hematoxylin. Negative controls were processed in the absence of primary antibody (D) (Magnification 200×). $\alpha$-SMA immunoreactive cells were noted surrounding vessel walls (arrows) in (A) and distributed in a pattern of thickened clusters of cells often surrounding terminal airways in other pneumonia and Ureaplasma cases (B and C). The extent of myofibroblast accumulation and percent of lung involvement was greater in Ureaplasma cases than in other pneumonia cases. Reprinted from Viscardi et al. Pediatr Dev Pathol 9:143151, Copyright @ 2006 Society for Pediatric Pathology and the Pediatric Pathology Society, with permission.

lished in the pulmonary compartment leads to inflammation and lung injury. Intratracheal Ureaplasma inoculation caused an acute bronchiolitis in $140 \mathrm{~d}$ preterm baboons (57), and an acute interstitial pneumonia in newborn, but not $14 \mathrm{~d}$ old mice (58). Hyperoxia exposure increased mortality, lung inflammation, and delayed pathogen clearance in Ureaplasmainoculated newborn mice (59), consistent with the hypothesis that Ureaplasma augments the inflammatory response to secondary stimuli. In mice, Ureaplasma intratracheal inoculation caused an acute pneumonitis, sustained inflammation up to $28 \mathrm{~d}$ postinoculation despite apparent clearance of the organism (60). Although these models demonstrate the direct effect of Ureaplasma in the lung, they lack the early developmental component.

Intrauterine Ureaplasma infection models have been developed in nonhuman primates $(61-64)$ and in fetal sheep $(65,66)$ that more closely mimic the human condition. In Rhesus monkeys, intraamniotic inoculation of $U$. parvum serovar 1 at $130 \mathrm{~d}$ gestation (term, $167 \mathrm{~d}$ ) increased uterine contractility, preceded by elevations in TNF- $\alpha$, IL-1ß, IL-6, and IL- 8 in AF and histologic evidence of chorioamnionitis $(61,62)$. Similar findings were observed in the $125 \mathrm{~d}$ immature baboon model infected with Ureaplasma in utero (63). Intra-amniotic Ureaplasma (serovar 1) inoculation $2 \mathrm{~d}$ before delivery at $125 \mathrm{~d}$ (67\% of term gestation) in the baboon caused an inflammatory response in the amniotic and fetal lung compartments and vertical transmission to the fetal lung that persisted up to $2 \mathrm{wk}$ postnatally in half of the antenatal-exposed animals. Compared with lungs from noninfected animals and gestational

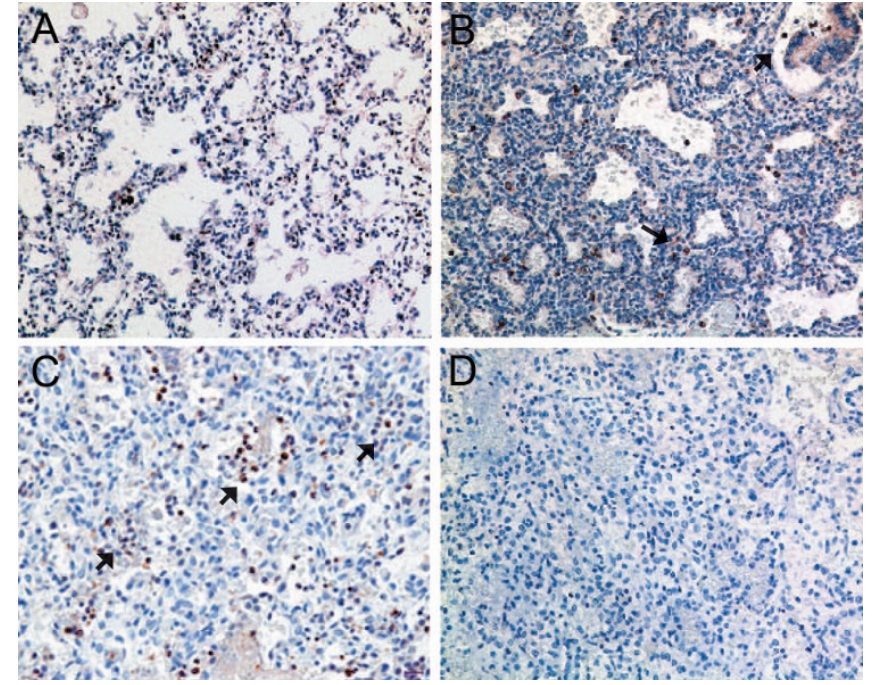

Figure 3. Comparison of TGF $\beta_{1}$ immunostaining in human lung specimens. (A) Control nonventilated infant at $23 \mathrm{wk} \mathrm{GA}$; (B) Other pneumonia case at 24 wk GA ventilated for $2 \mathrm{~d}$; and (C) Ureaplasma-infected infant at 26 wk GA ventilated for $20 \mathrm{~d}$. Lung sections were incubated with anti-TGFß $\beta_{1}$ antibody, stained with diaminobenzidine and counterstained with hematoxylin. Negative controls were processed in the absence of primary antibody (D) (Magnification $200 \times$ ). In lung specimens from infants dying with acute bacterial or Ureaplasma pneumonia, immunostaining was concentrated in focal aggregates of alveolar and interstitial macrophages. Reprinted from Viscardi et al. Pediatr Dev Pathol 9:143-151, Copyright (C) 2006 Society for Pediatric Pathology and the Pediatric Pathology Society, with permission.

controls, Ureaplasma-infected lungs demonstrated 1) more extensive fibrosis, increased myofibroblast phenotype (Fig. 4) and $\mathrm{TGFB}_{1}$ immunostaining (Fig. 5); 2) increased bronchoalveolar lavage concentrations of IL- $1 \beta$, and active TGF $\beta_{1}$, but no differences in IL-10; and 3) a trend toward greater activation of pro-fibrotic transcription factors Smad-2 and -3 relative to anti-fibrotic Smad-7 in lung homogenates, suggesting an imbalance of pro- and anti-fibrotic signaling factors in the Ureaplasma-infected animals. In fetal sheep exposed to intraamniotic Ureaplasma for periods up to $10 \mathrm{wks}$, long-term exposure was associated with improvement in lung function, but poor fetal growth, fetal acidemia, and evidence of fetal pulmonary inflammation (65). Intra-amniotic inoculation of $U$. parvum servovar 3 or 6 at mid-gestation in fetal sheep did not result in preterm labor, but did cause placental and fetal pulmonary inflammation and altered lung development whether delivery occurred preterm or at term (66). These data provide compelling evidence that antenatal Ureaplasma infection alters lung development and augments a prolonged, pro-inflammatory, pro-fibrotic response in the preterm lung exposed postnatally to ventilation and hyperoxia.

We propose that Ureaplasma may contribute to lung injury and fibrosis by modulating the local immune response to produce sustained chronic inflammation. Preterm infants with Ureaplasma respiratory colonization exhibited elevated tracheal aspirate IL- $1 \beta$, TNF- $\alpha$, and monocyte chemoattractant protein- 1 concentrations and neutrophil chemotactic activity during the first weeks of life compared with noncolonized infants (67-69). In the mouse Ureaplasma pneumonia model, intratracheal inoculation with Ureaplasma induced a pro- 


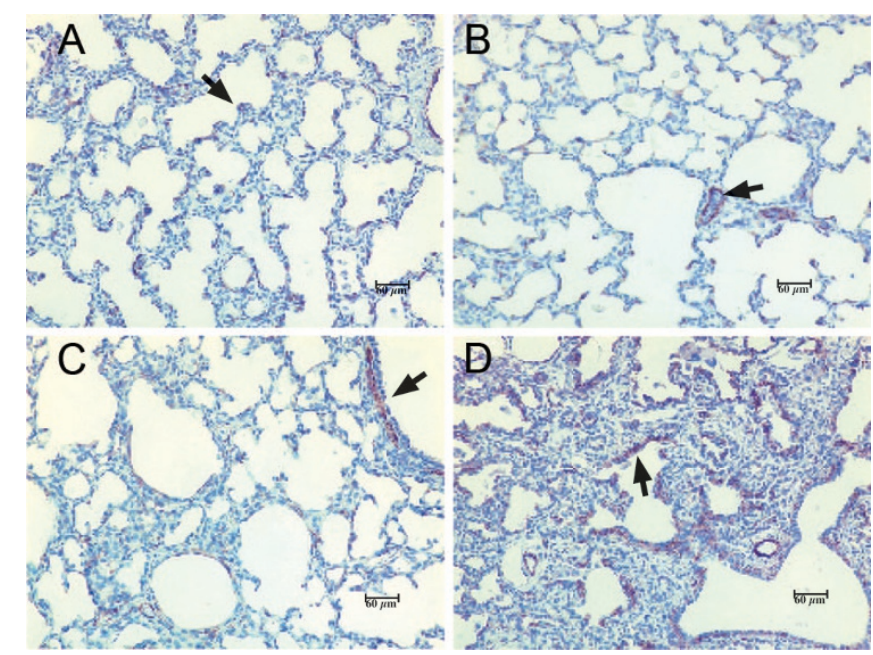

Figure 4. Alpha-SMA positive cells are increased in lung tissue form antenatal Ureaplasma-infected baboons. Lung sections were processed for immunohistochemical staining using a monoclonal anti-human antibody directed against $\alpha$-SMA (arrows). A) $125 \mathrm{~d}$ GC; B) $140 \mathrm{~d}$ GC; C) $125 \mathrm{~d}$ noninfected ventilated control; and D) 125d antenatal Ureaplasma-infected, ventilated baboon. Magnification 200X. Reprinted from Viscardi et al. Pediatr Res 60:141-146, Copyright (C) 2006 International Pediatric Research Foundation, Inc., with permission.

longed inflammatory response as indicated by a sustained recruitment of neutrophils and macrophages into the lung (60).

The stimulatory effect of Ureaplasma on cytokine release has been confirmed in vitro. In cultured human cord blood preterm monocytes, Ureaplasma stimulated release of TNF- $\alpha$ and IL-8, and when co-administered with Gram-negative lipopolysaccharide (LPS), Ureaplasma greatly augmented generation of pro-inflammatory cytokines while blocking expression of the counter-regulatory cytokines, IL- 6 and IL-10 (70). Ureaplasma stimulated TNF- $\alpha$ and IL-6 release, nitric oxide production, and up-regulation of iNOS, nuclear factorkappa B (NF- $\kappa \mathrm{B})$ activation, and VEGF and soluble and cell-associated ICAM-1 expression by human and murine derived monocytic cells (71-73). Ureaplasma induced apoptosis in A549 cells, a human type II cell line, and in THP-1 human monocytic cells (74). These effects could be partially blocked by anti-TNF- $\alpha$ MAb $(73,74)$, implicating TNF- $\alpha$ as a mediator of the host immune response to this infection that contributes to altered lung development.

\section{Ureaplasma TLR Signaling}

The Toll like receptors (TLRs) are "pattern recognition receptors" that are key components of the innate immune response to microbial products (75). The TLR family responds to a broad range of pathogen-associated molecular patterns (PAMPs), including LPS, viral coat proteins, bacterial lipoproteins and glycolipids, viral RNA, and CpG-containing bacterial DNA (75). Engagement of TLR proteins activates the expression of pro-inflammatory mediators by macrophages, neutrophils, dendritic cells, B cells, endothelial cells, and epithelial cells.

Recent studies by Peltier et al. (76) and Shimizu et al. (77) demonstrated that Triton X-114 detergent extracted lipopro-

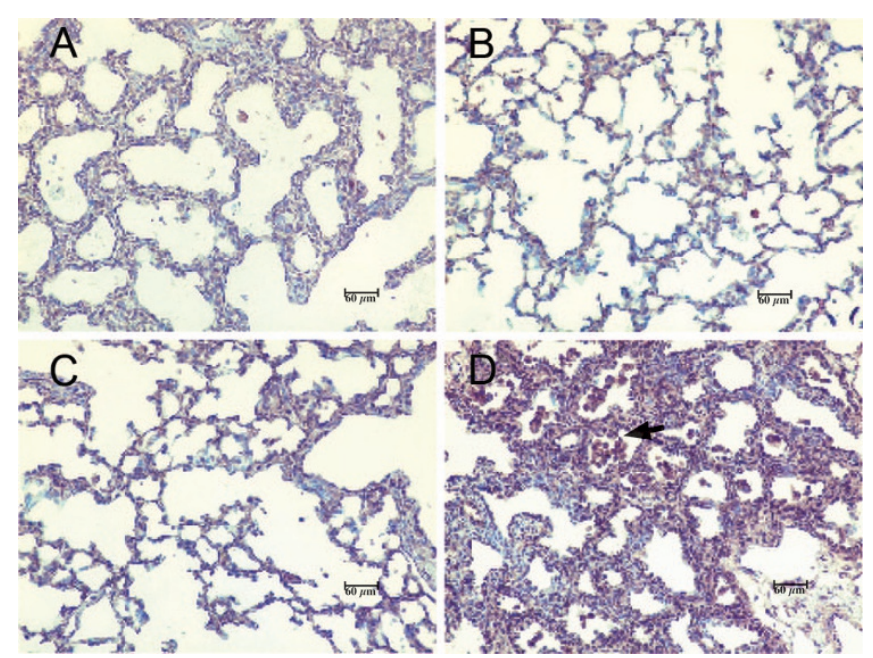

Figure 5. $T G F \beta_{1}$ immunostaining in lung specimens of antenatal Ureaplasmaexposed baboons is concentrated in focal aggregates of alveolar and interstitial macrophages. Lung sections were incubated with anti-TGFß $\beta_{1}$ antibody, stained with diaminobenzidine and counterstained with hematoxylin. A) 125d GC; B) 140d GC; C) 125d noninfected ventilated control; and D) 125d antenatal Ureaplasma-infected, ventilated baboon. Magnification 200X. Reprinted from Viscardi et al. Pediatr Res 60:141-146, Copyright (C) 2006 International Pediatric Research Foundation, Inc., with permission.

teins from $U$. urealyticum serovar 4 and $U$. parvum serovar 3, respectively, are responsible for NF- $\kappa \mathrm{B}$ activation. Active lipoproteins identified for serovar 3 included the MB antigen (77). The serovar 3 detergent extracts activated NF- $\kappa \mathrm{B}$ through TLR2 cooperatively with TLR1 and TLR6 (77), while serovar 4 extracts activated both TLR2 and TLR4 (76). Further studies will need to determine whether the different Ureaplasma species or serovars interact with different TLRs.

Little is known concerning TLR expression during human lung development. In mice, TLR2 and TLR4 mRNA levels were barely detectable early in gestation, increasing thereafter during late gestation and postnatally (78). In fetal sheep lung, TLR2 and TLR4 mRNA levels increased throughout late gestation to reach half of adult levels at term, but were induced by intra-amniotic LPS exposure (79). In the immature baboon model, TLR2 and TLR4 mRNA and protein expression were low in 125d and 140d nonventilated gestational controls, reached adult levels near term, and were increased in $125 \mathrm{~d}$ preterm baboons ventilated with oxygen for $21 \mathrm{~d}$ (80). These data may explain, in part, the developmental susceptibility to Ureaplasma infection and interaction with other stimuli. Low TLR2 and 4 expression early in gestation may increase the susceptibility of the fetal lung to Ureaplasma infection and delay clearance, but postnatal exposures to mechanical ventilation, oxygen, and other infections, may stimulate pulmonary TLR expression and enhance Ureaplasma-mediated inflammatory signaling.

\section{Therapeutic Considerations}

Despite in vitro susceptibility of Ureaplasma to erythromycin, trials of erythromycin therapy in the first few weeks of life in Ureaplasma colonized preterm infants failed to demonstrated efficacy to prevent BPD or eradicate respiratory tract colonization (reviewed in (10)). Combined antibiotic treatment with ceftriax- 
one, clindamycin, and erythromycin failed to eradicate Mycoplasma invasion of the amniotic cavity or resolve inflammation in most patients with preterm premature rupture of membranes (81). Lack of efficacy may have been due to the late timing or choice of antibiotic(s) or lack of combination with antiinflammatory drugs. In an experimental Ureaplasma intraamniotic infection (IAI) in Rhesus monkeys, azithromycin alone or in combination with dexamethasone and indocin prevented fetal lung damage (Novy MJ et al., Maternal azithromycin (AZI) therapy for Ureaplasma intraamnioitc infection (IAI) prevents advanced fetal lung lesions in rhesus monkeys, 2008 SGI Annual Scientific Meeting, March 26-29, 2008, San Diego, CA, Abstract 438).

Eradicating Ureaplasma spp. from the pregnant female genital tract and/or fetal/newborn lung may be difficult. Clinical isolates may vary in susceptibility to macrolide antibiotics due to 1) mutations in $23 \mathrm{~S}$ rRNA $(82)$; 2) presence of coinfection with Mycoplasma hominis (83); and 3) differences in ability to form protective biofilms (84). The pharmacokinetics, pharmacodynamics, and safety of macrolides in newborns are unknown and would need to be established before a randomized placebo-controlled trial of efficacy of these antibiotics to eradicate Ureaplasma infection or prevent BPD in the preterm population can be done.

Studies of the Ureaplasma genome and insight into the pathogen-host interactions may identify alternative drug and vaccine targets and lead to the development of biomarkers for early detection of infection. If essential membrane transporters lacking significant homology with human proteins are identified in the Ureaplasma spp. genomes, they might be attractive therapeutic targets for small molecule inhibitors or vaccines (85). The TLR activating lipoproteins are additional attractive targets for drug and/or vaccine development. Since most Ureaplasma IAIs are subclinical, there are currently no effective strategies for screening for affected pregnancies. Proteomic analysis of AF (61) and cervical-vaginal fluid (62) in experimental Rhesus monkey Ureaplasma intraamniotic infection revealed unique proteins that may be useful as specific biomarkers for detection of early intraamniotic infection. Future studies will need to focus on strategies for prevention and early detection of Ureaplasma intraamniotic infection, and the development of optimal antibiotic therapy for treating the infection in utero to reduce preterm birth and in the preterm newborn to prevent BPD.

\section{REFERENCES}

1. Jobe AH, Bancalari E 2001 Bronchopulmonary dysplasia. Am J Respir Crit Care Med 163:1723-1729

2. Viscardi RM, Muhumuza CK, Rodriguez A, Fairchild KD, Sun CC, Gross GW, Campbell AB, Wilson PD, Hester L, Hasday JD 2004 Inflammatory markers in intrauterine and fetal blood and cerebrospinal fluid compartments are associated with adverse pulmonary and neurologic outcomes in preterm infants. Pediatr Res 55:1009-1017

3. Husain AN, Siddiqui NH, Stocker JT 1998 Pathology of arrested acinar development in postsurfactant bronchopulmonary dysplasia. Hum Pathol 29:710-717

4. Sanchez PJ, Regan JA 1988 Ureaplasma urealyticum colonization and chronic lung disease in low birth weight infants. Pediatr Infect Dis J 7:542-546

5. Wang EE, Frayha H, Watts J, Hammerberg O, Chernesky MA, Mahony JB, Cassell GH 1988 Role of Ureaplasma urealyticum and other pathogens in the development of chronic lung disease of prematurity. Pediatr Infect Dis J 7:547-551

6. Cassell GH, Waites KB, Crouse DT, Rudd PT, Canupp KC, Stagno S, Cutter GR 1988 Association of Ureaplasma urealyticum infection of the lower respiratory tract with chronic lung disease and death in very-low-birth-weight infants. Lancet 2: $240-244$
7. Wang EE, Ohlsson A, Kellner JD 1995 Association of Ureaplasma urealyticum colonization with chronic lung disease of prematurity: Results of a metaanalysis. J Pediatr 127:640-644

8. Schelonka RL, Katz B, Waites KB, Benjamin DK Jr 2005 Critical appraisal of the role of Ureaplasma in the development of bronchopulmonary dysplasia with metaanalytic techniques. Pediatr Infect Dis J 24:1033-1039

9. Cassell GH, Waites KB, Watson HL, Crouse DT, Harasawa R 1993 Ureaplasma urealyticum intrauterine infection: role in prematurity and disease in newborns. Clin Microbiol Rev 6:69-87

10. Waites KB, Katz B, Schelonka RL 2005 Mycoplasmas and ureaplasmas as neonatal pathogens. Clin Microbiol Rev 18:757-789

11. Volgmann T, Ohlinger R, Panzig B 2005 Ureaplasma urealyticum-harmless commensal or underestimated enemy of human reproduction? A review. Arch Gynecol Obstet 273:133-139

12. Glass JI, Lefkowitz EJ, Glass JS, Heiner CR, Chen EY, Cassell GH 2000 The complete sequence of the mucosal pathogen Ureaplasma urealyticum. Nature 407:757-762

13. Abele-Horn M, Wolff C, Dressel P, Pfaff F, Zimmermann A 1997 Association of Ureaplasma urealyticum biovars with clinical outcome for neonates, obstetric patients, and gynecological patients with pelvic inflammatory disease. J Clin Microbiol 35:1199-1202

14. Grattard F, Soleihac B, De Barbeyrac B, Bebear C, Seffert P, Pozzetto B 1995 Epidemiologic and molecular investigations of genital mycoplasmas from women and neonates at delivery. Pediatr Infect Dis J 14:853-858

15. Hannaford K, Todd DA, Jeffrey H, John E, Byth K, Gilbert GL 1999 Role of Ureaplasma urealyticum in lung disease of prematurity. Arch Dis Child Fetal Neonatal Ed 81:F162-F167

16. Viscardi RM, Hashmi N, Gross GW, Sun CC, Rodriguez A, Fairchild KD 2008 Incidence of invasive ureaplasma in VLBW infants: relationship to severe intraventricular hemorrhage. J Perinatol 28:759-765

17. Katz B, Patel P, Duffy L, Schelonka RL, Dimmitt RA, Waites KB 2005 Characterization of ureaplasmas isolated from preterm infants with and without bronchopulmonary dysplasia. J Clin Microbiol 43:4852-4854

18. Kirchner L, Helmer H, Heinze G, Wald M, Brunbauer M, Weninger M, Zaknun D 2007 Amnionitis with Ureaplasma urealyticum or other microbes leads to increased morbidity and prolonged hospitalization in very low birth weight infants. Eur J Obstet Gynecol Reprod Biol 134:44-50

19. Yoon BH, Romero R, Kim M, Kim EC, Kim T, Park JS, Jun JK 2000 Clinical implications of detection of Ureaplasma urealyticum in the amniotic cavity with the polymerase chain reaction. Am J Obstet Gynecol 183:1130-1137

20. Abele-Horn M, Peters J, Genzel-Boroviczeny O, Wolff C, Zimmermann A, Gottschling W 1997 Vaginal Ureaplasma urealyticum colonization: influence on pregnancy outcome and neonatal morbidity. Infection 25:286-291

21. Kafetzis DA, Skevaki CL, Skouteri V, Gavrili S, Peppa K, Kostalos C, Petrochilou V, Michalas S 2004 Maternal genital colonization with Ureaplasma urealyticum promotes preterm delivery: association of the respiratory colonization of premature infants with chronic lung disease and increased mortality. Clin Infect Dis 39:11131122

22. Colaizy TT, Morris CD, Lapidus J, Sklar RS, Pillers DA 2007 Detection of ureaplasma DNA in endotracheal samples is associated with bronchopulmonary dysplasia after adjustment for multiple risk factors. Pediatr Res 61:578-583

23. Alfa MJ, Embree JE, Degagne P, Olson N, Lertzman J, MacDonald KS, MacDonald NT, Hall PF 1995 Transmission of Ureaplasma urealyticum from mothers to full and preterm infants. Pediatr Infect Dis J 14:341-345

24. Iles R, Lyon A, Ross P, McIntosh N 1996 Infection with Ureaplasma urealyticum and Mycoplasma hominis and the development of chronic lung disease in preterm infants. Acta Paediatr 85:482-484

25. Garland SM, Bowman ED 1996 Role of Ureaplasma urealyticum and Chlamydia trachomatis in lung disease in low birth weight infants. Pathology 28:266-269

26. Pacifico L, Panero A, Roggini M, Rossi N, Bucci G, Chiesa C 1997 Ureaplasma urealyticum and pulmonary outcome in a neonatal intensive care population. Pediatr Infect Dis J 16:579-586

27. Perzigian RW, Adams JT, Weiner GM, Dipietro MA, Blythe LK, Pierson CL, Faix RG 1998 Ureaplasma urealyticum and chronic lung disease in very low birth weight infants during the exogenous surfactant era. Pediatr Infect Dis J 17:620-625

28. Abele-Horn M, Genzel-Boroviczeny O, Uhlig T, Zimmermann A, Peteres J, Scholz M 1998 Ureaplasma urealyticum colonization and bronchopulmonary dysplasia: a comparative prospective muticentre study. Eur J Pediatr 157:1004-1011

29. Da Silva O, Gregson D, Hammerberg O 1997 Role of Ureaplasma urealyticum and Chlamydia trachomatis in development of bronchopulmonary dysplasia in very low birth weight infants. Pediatr Infect Dis J 16:364-369

30. van Waarde WM, Brus F, Okken A, Kimpen JL 1997 Ureaplasma urealyticum colonization, prematurity and bronchopulmonary dysplasia. Eur Respir J 10:886890

31. Couroucli XI, Welty SE, Ramsay PL, Wearden ME, Fuentes-Garcia FJ, Ni J, Jacobs TN, Towbin JA, Bowles NE 2000 Detection of microorganisms in the tracheal aspirates of preterm infants by polymerase chain reaction: association of adenovirus infection with bronchopulmonary dysplasia. Pediatr Res 47:225-232

32. Heggie AD, Bar-Shain D, Boxerbaum B, Fanaroff AA, O'Riordan MA, Robertson JA 2001 Identification and quantification of ureaplasmas colonizing the respiratory tract and assessment of their role in the development of chronic lung disease in preterm infants. Pediatr Infect Dis J 20:854-859

33. Honma Y, Yada Y, Takahashi N, Momoi MY, Nakamura Y 2007 Certain type of chronic lung disease of newborns is associated with Ureaplasma urealyticum infection in utero. Pediatr Int 49:479-484 
34. Gray DJ, Robinson HB, Malone J, Thomson RB Jr 1992 Adverse outcome in pregnancy following amniotic fluid isolation of Ureaplasma urealyticum. Prenat Diagn 12:111-117

35. Horowitz S, Mazor M, Romero R, Horowitz J, Glezerman M 1995 Infection of the amniotic cavity with Ureaplasma urealyticum in the midtrimester of pregnancy. J Reprod Med 40:375-379

36. Berg TG, Philpot KL, Welsh MS, Sanger WG, Smith CV 1999 Ureaplasma/ Mycoplasma-infected amniotic fluid: pregnancy outcome in treated and nontreated patients. J Perinatol 19:275-277

37. Perni SC, Vardhana S, Korneeva I, Tuttle SL, Paraskevas LR, Chasen ST, Kalish RB, Witkin SS Mycoplasma hominis and Ureaplasma urealyticum in midtrimester amniotic fluid: association with amniotic fluid cytokine levels and pregnancy outcome. Am J Obstet Gynecol 191:1382-1386, 2004

38. Bashiri A, Horowitz S, Huleihel M, Hackmon R, Dukler D, Mazor M 1999 Elevated concentrations of interleukin-6 in intra-amniotic infection with Ureaplasma urealyticum in asymptomatic women during genetic amniocentesis. Acta Obstet Gynecol Scand 78:379-382

39. Castro-Alcaraz S, Greenberg EM, Bateman DA, Regan JA 2002 Patterns of colonization with Ureaplasma urealyticum during neonatal intensive care unit hospitalizations of very low birth weight infants and the development of chronic lung disease. Pediatrics 110:e45

40. Goldenberg RL, Andrews WW, Goepfert AR, Faye-Petersen O, Cliver SP, Carlo WA, Hauth JC 2008 The Alabama Preterm Birth Study: umbilical cord blood Ureaplasma urealyticum and Mycoplasma hominis cultures in very preterm newborn infants. Am J Obstet Gynecol 198:43.e1-e5

41. Yoon BH, Romero R, Jun JK, Park KH, Park JD, Ghezzi F, Kim BI 1997 Amniotic fluid cytokines (interleukin-6, tumor necrosis factor- $\alpha$, interleukin-1ß, and interleukin-8) and the risk for the development of bronchopulmonary dysplasia. Am J Obstet Gynecol 177:825-830

42. Bagchi A, Viscardi RM, Taciak V, Ensor JE, McCrea KA, Hasday JD 1994 Increased activity of interleukin- 6 but not tumor necrosis factor- $\alpha$ in lung lavage of premature infants is associated with the development of bronchopulmonary dysplasia. Pediatr Res 36:244-252

43. Rindfleisch MS, Hasday JD, Taciak V, Broderick K, Viscardi RM 1996 Potential role of interleukin-1 in the development of bronchopulmonary dysplasia. J Interferon Cytokine Res 16:365-373

44. Viscardi RM, Hasday JD, Gumpper KF, Taciak V, Campbell AB, Palmer TW 1997 Cromolyn sodium prophylaxis inhibits pulmonary proinflammatory cytokines in infants at high risk for bronchopulmonary dysplasia. Am J Respir Crit Care Med 156:1523-1529

45. Jones CA, Cayabyab RG, Kwong KY, Stotts C, Wong B, Hamdan H, Minoo P, deLemos RA 1996 Undetectable interleukin (IL)-10 and persistent IL-8 expression early in hyaline membrane disease: a possible developmental basis for the predisposition to chronic lung inflammation in preterm newborns. Pediatr Res 39:966-975

46. Bose CL, Dammann CE, Laughon MM 2008 Bronchopulmonary dysplasia and inflammatory biomarkers in the premature neonate. Arch Dis Child Fetal Neonatal Ed 93:F455-F461

47. Bry K, Whitsett JA, Lappalainen U 2007 IL-1beta disrupts postnatal lung morphogenesis in the mouse. Am J Respir Cell Mol Biol 36:32-42

48. Warburton D, Tefft D, Mailleux A, Bellusci S, Thiery JP, Zhao J, Buckley S, Shi W, Driscoll B 2001 Do lung remodeling, repair, and regeneration recapitulate respiratory ontogeny? Am J Respir Crit Care Med 164:S59-S62

49. Toti P, Buonocore G, Tanganelli P, Catella AM, Palmeri ML, Vatti R, Seemayer TA 1997 Bronchopulmonary dysplasia of the premature baby: an immunohistochemical study. Pediatr Pulmonol 24:22-28

50. Vicencio AG, Lee CG, Cho SJ, Eickelberg O, Chuu Y, Haddad GG, Elias JA 2004 Conditional overexpression of bioactive transforming growth factor-betal in neonatal mouse lung: a new model for bronchopulmonary dysplasia? Am J Respir Cell Mol Biol 31:650-656

51. Gauldie J, Galt T, Bonniaud P, Robbins C, Kelly M, Warburton D 2003 Transfer of the active form of transforming growth factor-beta 1 gene to newborn rat lung induces changes consistent with bronchopulmonary dysplasia. Am J Pathol $163: 2575-2584$

52. Sime PJ, Marr RA, Gauldie D, Xing Z, Hewlett BR, Graham FL, Gauldie J 1998 Transfer of tumor necrosis factor-alpha to rat lung induces severe pulmonary inflammation and patchy interstitial fibrogenesis with induction of transforming growth factor-beta1 and myofibroblasts. Am J Pathol 153:825-832

53. Kolb M, Margetts P, Anthony D, Pitossi F, Gauldie J 2001 Transient expression of IL-1B induces acute lung injury and chronic repair leading to pulmonary fibrosis. J Clin Invest 107:1529-1536

54. Lecart C, Cayabyab R, Buckley S, Morrison J, Kwong KY, Warburton D, Ramanathan R, Jones CA, Minoo P 2000 Bioactive transforming growth factor-beta in the lungs of extremely low birthweight neonates predicts the need for home oxygen supplementation. Biol Neonate 77:217-223

55. Viscardi RM, Manimtim WM, Sun CC, Duffy L, Cassell GH 2002 Lung pathology in premature infants with Ureaplasma urealyticum infection. Pediatr Dev Pathol 5:141-150

56. Viscardi R, Manimtim W, He JR, Hasday JD, Sun CC, Joyce B, Pierce RA 2006 Disordered pulmonary myofibroblast distribution and elastin expression in preterm infants with Ureaplasma urealyticum pneumonitis. Pediatr Dev Pathol 9:143-151

57. Walsh WF, Butler J, Coalson J, Hensley D, Cassell GH, deLemos RA 1993 A primate model of Ureaplasma urealyticum infection in the premature infant with hyaline membrane disease. Clin Infect Dis 17:S158-S162

58. Rudd PT, Cassell GH, Waites KB, Davis JK, Duffy LB 1989 Ureaplasma urealyticum pneumonia: experimental production and demonstration of age-related susceptibility. Infect Immun 57:918-925
59. Crouse DT, Cassell GH, Waites KB, Foster JM, Cassady G 1990 Hyperoxia potentiates Ureaplasma urealyticum pneumonia in newborn mice. Infect Immun 58:3487-3493

60. Viscardi RM, Kaplan J, Lovchik JC, He JR, Hester L, Rao S, Hasday JD 2002 Characterization of a murine model of Ureaplasma urealyticum pneumonia. Infect Immun 70:5721-5729

61. Gravett MG, Novy MJ, Rosenfeld RG, Reddy AP, Jacob T, Turner M, McCormack A, Lapidus JA, Hitti J, Eschenbach DA, Roberts CT Jr., Nagalla SR 2004 Diagnosis of intra-amniotic infection by proteomic profiling and identification of novel biomarkers. JAMA 292:462-469

62. Gravett MG, Thomas A, Schneider KA, Reddy AP, Dasari S, Jacob T, Lu X, Rodland M, Pereira L, Sadowsky DW, Roberts CT Jr., Novy MJ, Nagalla SR 2007 Proteomic analysis of cervical-vaginal fluid: identification of novel biomarkers for detection of intra-amniotic infection. J Proteome Res 6:89-96

63. Yoder BA, Coalson JJ, Winter VT, Siler-Khodr T, Duffy LB, Cassell GH 2003 Effects of antenatal colonization with Ureaplasma urealyticum on pulmonary disease in the immature baboon. Pediatr Res 54:797-807

64. Viscardi RM, Atamas SP, Luzina IG, Hasday JD, He JR, Sime PJ, Coalson JJ, Yoder BA 2006 Antenatal Ureaplasma urealyticum respiratory tract infection stimulates proinflammatory, profibrotic responses in the preterm baboon lung. Pediatr Res 60:141-146

65. Moss TJ, Nitsos I, Ikegami M, Jobe AH, Newnham JP 2005 Experimental intrauterine Ureaplasma infection in sheep. Am J Obstet Gynecol 192:1179-1186

66. Moss TJ, Knox CL, Kallapur SG, Nitsos I, Theodoropoulos C, Newnham JP, Ikegami M, Jobe AH 2008 Experimental amniotic fluid infection in sheep: effects of Ureaplasma parvum serovars 3 and 6 on preterm or term fetal sheep. Am J Obstet Gynecol 198:122.e1-e8

67. Groneck P, Goetze-Speer B, Speer CP 1996 Inflammatory bronchopulmonary response of preterm infants with microbial colonisation of the airways at birth. Arch Dis Child Fetal Neonatal Ed 74:F51-F55

68. Patterson AM, Taciak V, Lovchik J, Fox RE, Campbell AB, Viscardi RM 1998 Ureaplasma urealyticum respiratory tract colonization is associated with an increase in IL- $1 \beta$ and TNF- $\alpha$ relative to IL-6 in tracheal aspirates of preterm infants. Pediatr Infect Dis J 17:321-328

69. Baier RJ, Loggins J, Kruger TE 2001 Monocyte chemoattractant protein-1 and interleukin-8 are increased in bronchopulmonary dysplasia: relation to isolation of Ureaplasma urealyticum. J Investig Med 49:362-369

70. Manimtim WM, Hasday JD, Hester L, Fairchild KD, Lovchik JC, Viscardi RM 2001 Ureaplasma urealyticum modulates endotoxin-induced cytokine release by human monocytes derived from preterm and term newborns and adults. Infect Immun 69:3906-3915

71. Li YH, Brauner A, Jonsson B, Van der Ploeg I, Soder O, Holst M, Jensen JS, Lagercrantz H, Tullus K 2000 Ureaplasma urealyticum-induced production of proinflammatory cytokines by macrophages. Pediatr Res 48:114-119

72. Li YH, Yan ZQ, Jensen JS, Tullus K, Brauner A 2000 Activation of nuclear factor kappaB and induction of inducible nitric oxide synthase by ureaplasma urealyticum in macrophages. Infect Immun 68:7087-7093

73. Li YH, Brauner A, Jensen JS, Tullus K 2002 Induction of human macrophage vascular endothelial growth factor and intercellular adhesion molecule-1 by Ureaplasma urealyticum and downregulation by steroids. Biol Neonate 82:22-28

74. Li YH, Chen M, Brauner A, Zheng C, Skov Jensen J, Tullus K 2002 Ureaplasma urealyticum induces apoptosis in human lung epithelial cells and macrophages. Biol Neonate 82:166-173

75. Kaisho T, Akira S 2004 Pleiotropic function of Toll-like receptors. Microbes Infect 6:1388-1394

76. Peltier MR, Freeman AJ, Mu HH, Cole BC 2007 Characterization of the macrophage-stimulating activity from Ureaplasma urealyticum. Am J Reprod Immunol 57:186-192

77. Shimizu T, Kida Y, Kuwano K 2008 Ureaplasma parvum lipoproteins, including MB antigen, activate NF- $\{\varkappa\} \mathrm{B}$ through TLR1, TLR2 and TLR6. Microbiology $154: 1318-1325$

78. Harju K, Glumoff V, Hallman M 2001 Ontogeny of Toll-like receptors Tlr2 and Tlr4 in mice. Pediatr Res 49:81-83

79. Hillman NH, Moss TJ, Nitsos I, Kramer BW, Bachurski CJ, Ikegami M, Jobe AH, Kallapur SG 2008 Toll-like receptors and agonist responses in the developing fetal sheep lung. Pediatr Res 63:388-393

80. Awasthi S, Cropper J, Brown KM 2008 Developmental expression of Toll-like receptors-2 and -4 in preterm baboon lung. Dev Comp Immunol 32:1088-1098

81. Gomez R, Romero R, Nien JK, Medina L, Carstens M, Kim YM, Espinoza J, Chaiworapongsa T, Gonzalez R, Iams JD, Rojas I 2007 Antibiotic administration to patients with preterm premature rupture of membranes does not eradicate intraamniotic infection. J Matern Fetal Neonatal Med 20:167-173

82. Dongya M, Wencheng X, Xiaobo M, Lu W 2008 Transition mutations in 23S rRNA account for acquired resistance to macrolides in Ureaplasma urealyticum. Microb Drug Resist 14:183-186

83. Huang C, Liu Z, Lin N, Tu Y, Li J, Zhang D 2003 Susceptibility of mixed infection of Ureaplasma Urealyticum and Mycoplasma Hominis to seven antimicrobial agents and comparison with that of Ureaplasma Urealyticum infection. J Huazhong Univ Sci Technolog Med Sci 23:203-205

84. Garcia-Castillo M, Morosini MI, Galvez M, Baquero F, Del Campo R, Meseguer MA 2008 Differences in biofilm development and antibiotic susceptibility among clinical Ureaplasma urealyticum and Ureaplasma parvum isolates. J Antimicrob Chemother 62:1027-1030

85. Sudhakar P, Subramani P 2007 The transportome of the human mucosal pathogen Ureaplasma urealyticum. Lethbridge Undergraduate Research Journal 2:1-15 